\title{
Salp-falls in the Tasman Sea: a major food input to deep-sea benthos
}

\author{
Natasha Henschke ${ }^{1,2, *}$, David A. Bowden ${ }^{3}$, Jason D. Everett ${ }^{1,2,4}$, Sebastian P. Holmes ${ }^{5,6}$, \\ Rudy J. Kloser ${ }^{7}$, Raymond W. Lee $^{8}$, Iain M. Suthers ${ }^{1,2}$ \\ ${ }^{1}$ Evolution and Ecology Research Centre, University of New South Wales, Sydney, New South Wales 2052, Australia \\ ${ }^{2}$ Sydney Institute of Marine Science, Building 22, Chowder Bay Road, Mosman, New South Wales 2088, Australia \\ ${ }^{3}$ National Institute of Water and Atmospheric Research Ltd. (NIWA), 301 Evans Bay Parade, Greta Point, Wellington 6021, \\ New Zealand \\ ${ }^{4}$ Plant Functional Biology and Climate Change Cluster, Faculty of Science, University of Technology Sydney, PO Box 123 \\ Broadway, New South Wales 2007, Australia \\ ${ }^{5}$ School of Biological Sciences, University of Sydney, Sydney, New South Wales 2006, Australia \\ ${ }^{6}$ Water \& Wildlife Ecology Group (WWEG), School of Science \& Health, University of Western Sydney (UWS), Penrith, \\ New South Wales 1797, Australia \\ ${ }^{7}$ Commonwealth Scientific and Industrial Research Organisation (CSIRO) Marine Laboratories, PO Box 1538, Hobart, \\ Tasmania 7001, Australia \\ ${ }^{8}$ School of Biological Sciences, Washington State University, PO Box 644236, Pullman, Washington 99164-4236, USA
}

\begin{abstract}
Large, fast-sinking carcasses (food-falls) are an important source of nutrition to deepsea benthic communities. In 2007 and 2009, mass depositions of the salp Thetys vagina were observed on the Tasman Sea floor between 200 and $2500 \mathrm{~m}$ depth, where benthic crustaceans were observed feeding on them. Analysis of a long-term (1981 to 2011) trawl survey database determined that salp biomass (wet weight, WW) in the eastern Tasman Sea regularly exceeds $100 \mathrm{t} \mathrm{km}^{-3} \mathrm{yr}^{-1}$, with biomasses as high as $734 \mathrm{t} \mathrm{km}^{-3}$ recorded in a single trawl. With fast sinking rates, salp fluxes to the seafloor occur year-round. Salps, like jellyfish, have been considered to be of low nutritional value; however, biochemical analyses revealed that $T$. vagina has a carbon $(31 \%$ dry weight, DW) and energy (11.00 $\left.\mathrm{kJ} \mathrm{g}^{-1} \mathrm{DW}\right)$ content more similar to that of phytoplankton blooms, copepods and fish than to that of jellyfish, with which they are often grouped. The deposition of the mean yearly biomass $\left(4.81 \mathrm{t} \mathrm{km}^{-2} \mathrm{WW}\right)$ of salps recorded from the trawl database in the Tasman Sea represents a $330 \%$ increase to the carbon input normally estimated for this region. Given their abundance, rapid export to the seabed and high nutritional value, salp carcasses are likely to be a significant input of carbon to benthic food webs, which, until now, has been largely overlooked.
\end{abstract}

KEY WORDS: Benthic communities · Gelatinous zooplankton · Carbon cycling · Fluxes · Salp-fall · Jelly-fall

Resale or republication not permitted without written consent of the publisher

\section{INTRODUCTION}

Food-limited deep-sea benthic ecosystems rely on depositions of organic matter from the euphotic zone (Gooday 2002). Concentrated pulses of particulate organic matter (POM) derived from differing sources including phytoplankton blooms, other plant or algal matter, zooplankton faecal pellets and carcasses of larger fauna are major contributors of organic matter to the sea floor (Rowe \& Staresinic 1979, Smith et al. 2008). Despite the majority of particles being small (<5 mm) (Alldredge \& Silver 1988), these pulses are 
an important source of nutrition for deep-sea benthic communities, promoting both species richness and abundance (Butman et al. 1995). Benthic ecosystem functions are also positively related to increasing POM supply, including sediment community respiration rates and organic matter remineralisation (Witte \& Pfannkuche 2000, Smith et al. 2008, Sweetman \& Witte 2008).

Large, fast-sinking particles, such as carcasses, provide food-fall events that augment the nutritional ecology of deep-sea benthic communities (Rowe \& Staresinic 1979, Stockton \& DeLaca 1982, Smith \& Baco 2003). The 'gelatinous pathway' (Billett et al. 2006, Lebrato et al. 2012) was first discovered by Moseley (1880) and illustrates the potential for sinking carcasses of gelatinous organisms to contribute a large flux of organic matter to the benthic environment. Because of their swarming nature, depositions of gelatinous carcasses generally accumulate in high densities to the benthic environment in areas underlying large and persistent gelatinous populations (Billett et al. 2006, Lebrato \& Jones 2009). For example, following swarms in surface waters (Wiebe et al. 1979, Grassle \& Morse-Porteous 1987), dense concentrations of salp carcasses were observed nearby on the seafloor in the outer Hudson Canyon (3240 m) in 1975 and 1986 (Cacchione et al. 1978). Similarly, pelagic cnidarian deposits (jelly-falls) have been recorded on the sea floor off Oman (Billett et al. 2006), in the Sea of Japan (Yamamoto et al. 2008) and in a Norwegian fjord (Sweetman \& Chapman 2011), while pyrosome carcasses have been observed on the Madeira Abyssal Plain (Roe et al. 1990) and on the seafloor off the Ivory Coast (Lebrato \& Jones 2009).

During 2 benthic sampling research voyages, we observed mass depositions of the large salp Thetys vagina on the Tasman Sea floor, prompting an examination into their subsequent fate and the nutritional value provided by the carcasses to the deep-sea benthic communities. T. vagina reaches up to $306 \mathrm{~mm}$ in size (Nakamura \& Yount 1958) and has a distribution spanning the top $200 \mathrm{~m}$ (Thompson 1948, Iguchi \& Kidokoro 2006) of sub-tropical and temperate waters of the Mediterranean Sea and the Atlantic, Indian and Pacific oceans (Berrill 1950). Salp carcasses can potentially sink at rates of up to $1700 \mathrm{~m} \mathrm{~d}^{-1}$ (Lebrato et al. 2013), suggesting that little, if any, decomposition occurs during descent, and mass depositions of salp carcasses may represent an important and substantial food-fall event for the benthic ecosystem. Although several reports indicate that gelatinous organisms such as salps are important to the diet of some marine organisms (e.g. Duggins 1981, Clark et al. 1989, Lyle \& Smith 1997, Gili et al. 2006), they are still generally thought to be of low nutritional value (Moline et al. 2004). Therefore, to determine whether salp carcasses can positively contribute to the benthic ecosystem, it is necessary to identify the quality of food they provide.

In particular, we sought to (1) assess the frequency and abundance of salp swarms in the Tasman Sea and eastern New Zealand over $30 \mathrm{yr}$, (2) quantify the biomass and relative abundance of Thetys vagina carcasses on the sea floor, and (3) compare the energetic input and the biochemical composition of $T$. vagina carcasses with other gelatinous zooplankton.

\section{MATERIALS AND METHODS}

\section{Study region}

Long-term trawl surveys and 2 benthic sampling cruises were conducted in the southern Tasman Sea and Pacific Ocean east of New Zealand (Fig. 1A). For the first benthic study on board the RV 'Tangaroa' in June 2007 (TAN0707), sampling was carried out on the Challenger Plateau, a large submarine plateau extending from the west coast of central New Zealand and considered to be a region of low pelagic productivity (Wood 1991). In October 2009, on the second benthic study on board the RV 'Southern Surveyor' (SS03/2009), sampling occurred off southeastern Australia in Bass Canyon, one of the largest submarine canyons in the world (Mitchell et al. 2007).

\section{Trawl data analysis}

Trawl data were available from 2 sources: a longterm data series (30 yr) from the New Zealand fisheries research trawl database and pelagic trawls in the Tasman Sea over 3 yr. Salp and pyrosome biomass was obtained from analysis of the New Zealand fisheries database (stock assessment, research and observer-monitored commercial trawls) from 1981 to 2011 ( $\mathrm{n}=2044$; see Fig 1A for sampling locations). As the majority of data was opportunistically sampled, sampling periods within a year are variable but on average include every month per year. Trawls (midwater or benthic) were towed at a mean depth of $563.17 \pm 342.40 \mathrm{~m}$, ranging from 33 to $2532 \mathrm{~m}$. Where possible, recorded trawl dimensions and tow lengths were used. If details of trawl size or tow distance were not available, a standard averaged value calculated from all trawls was used (headline height $=8 \mathrm{~m}$, 

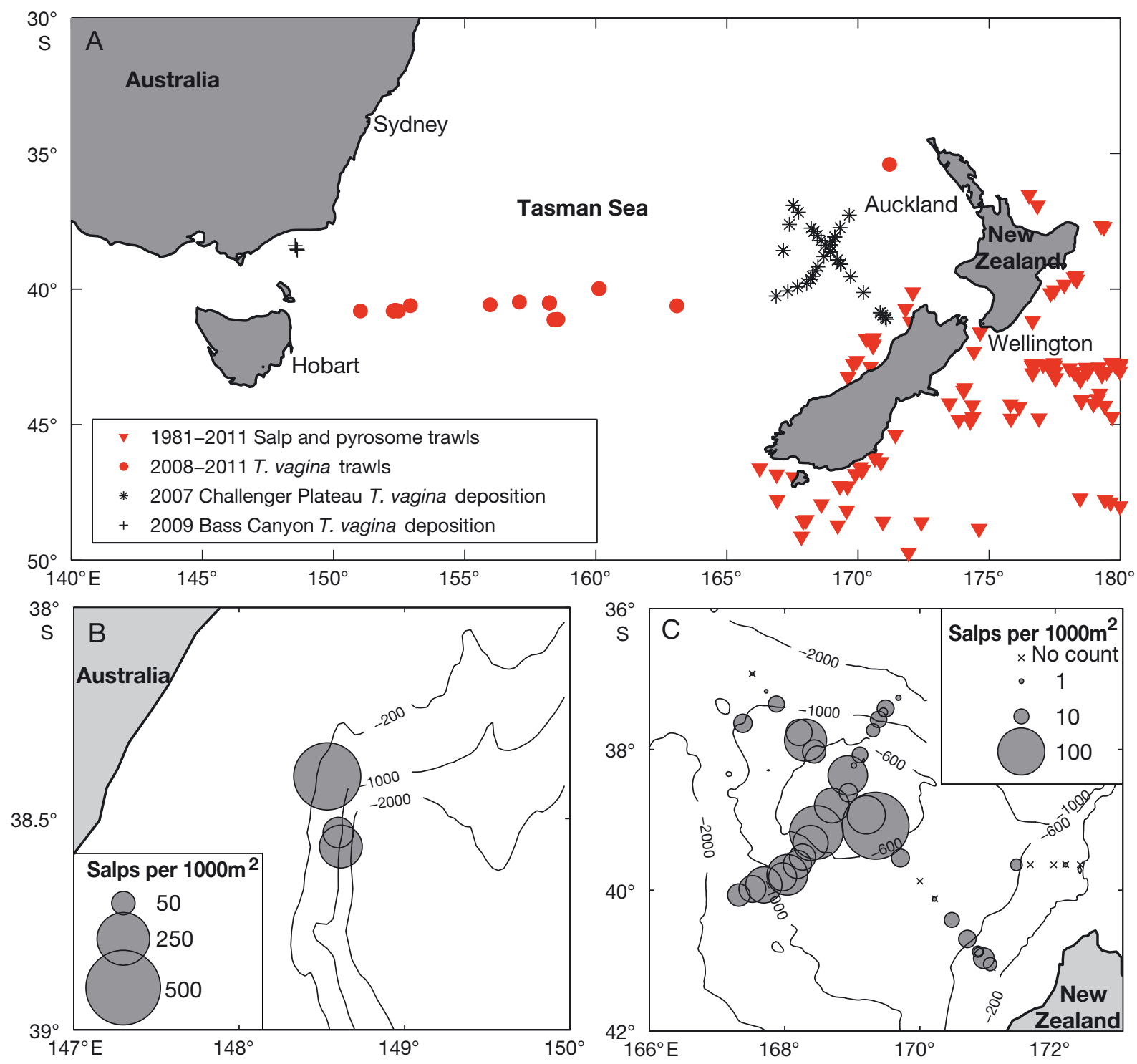

Fig. 1. (A) Survey area in the southern Tasman Sea and southwestern Pacific Ocean east of New Zealand showing trawl stations and benthic sampling stations. (B,C) Density distribution based on video footage/camera stills of Thetys vagina (ind. 1000 $\mathrm{m}^{-2}$ ) at different stations (B) in Bass Canyon and (C) on the Challenger Plateau. Depth contours are displayed in metres

wing distance $=30 \mathrm{~m}$, tow distance $=4.4 \mathrm{~km}$, tow speed $=6.5 \mathrm{~km} \mathrm{~h}^{-1}$ ). Individuals were not classified into species. Thetys vagina biomass was obtained from 3 trans-Tasman cruises in 2008, 2009 and 2011 $(\mathrm{n}=12)$. Depth-stratified midwater tows with a pelagic trawl were made at $200 \mathrm{~m}$ intervals to a maximum depth of $1000 \mathrm{~m}$ from the surface, with equal 20 min tows at $6.5 \mathrm{~km} \mathrm{~h}^{-1}$. The biomass estimates of $T$. vagina from the trans-Tasman pelagic trawls were calculated from the net area with the smallest mesh size capable of capturing them (minimum $40 \mathrm{~mm}$ mesh). Graded mesh area information was not available for the nets used in the New Zealand fisheries database, and as a result, biomass estimates are more conservative than data obtained from the transTasman pelagic trawls. All biomass estimates are represented in wet weight (WW).

\section{Benthic sample collection and analysis}

At both benthic sampling locations, video surveys were conducted using towed camera platforms with video and still image cameras. All individual salps observed on the seabed were counted along the full length of each video transect. If necessary, still camera images taken every 2 min along the transects were used to aid in identification of individuals. 
Deployments lasted from 30 to $60 \mathrm{~min}$, at speeds of 0.25 to $0.50 \mathrm{~ms}^{-1}$. On the Challenger Plateau, 46 deployments of the Deep Towed Imaging System (Hill 2009) were conducted at depths ranging from 237 to $1831 \mathrm{~m}$. Both video and still cameras were oriented directly downwards, to facilitate scaling, and video frame width was calculated in ImageJ (http://rsbweb.nih.gov/ij/) by measuring widths of approximately 100 frame grabs using the camera's paired lasers (20 cm apart) as a reference. In Bass Canyon, the Benthic Optical and Acoustic Grab System (Sherlock et al. 2010) was deployed at 3 depths: 450, 650 and $1500 \mathrm{~m}$. As the camera system did not have paired lasers, video frame width was measured by using the average $( \pm \mathrm{SD}$ ) length of Thetys vagina species caught from the subsequent Bass Canyon trawls $(55.66 \pm 5.90 \mathrm{~mm}, \mathrm{n}=30)$ to approximate frame size from 17 randomly chosen screenshots containing T. vagina. Abundance of individuals per $1000 \mathrm{~m}^{2}$ (ind. $1000 \mathrm{~m}^{-2}$ ) was calculated by determining salps per corrected area of deployments (corrected area = transect seabed area $\times$ percentage of usable video footage). Video analyses were run in Ocean Floor Observation Protocol (http://ofop.texel.com); see methods in Bowden et al. (2011). Still image analyses used ImageJ software.

After each towed camera transect, benthic fauna were sampled at the same site using either a beam trawl (4 m mouth width, $10 \mathrm{~mm}$ mesh) or an epibenthic sled (1 m mouth width, $25 \mathrm{~mm}$ mesh). Trawls were towed for approximately $15 \mathrm{~min}$ at $0.75 \mathrm{~m} \mathrm{~s}^{-1}$. Once back on deck, all fauna were sorted into species, weighed for biomass estimates and frozen $\left(-20^{\circ} \mathrm{C}\right)$.

Salps were thawed, and total length and wet weight were measured for each individual. Guts were removed prior to biochemical analysis to ensure that only body tissue was analysed. Randomly selected individuals from each site were then freeze-dried and their dry weights (DW) recorded. To determine ash-free dry weight (AFDW) of the specimens, tissue samples were taken and combusted at $550^{\circ} \mathrm{C}$ for $24 \mathrm{~h}$. All remaining tissue was ground in a ball mill to give a homogenous powder for biochemical analyses.

\section{Biochemical analyses}

Protein content of the salps was measured using the Bradford protein assay (Bradford 1976) with bovine serum albumin as the standard. Lipid content of the salps was estimated using a chloroform: methanol procedure after Folch et al. (1957) and carbohydrate content was estimated following Dubois et al. (1956) with D-glucose as the standard. Energetic values of the salps were determined with a Parr 6200 isoperibol calorimeter using a benzoic acid standard and as per the manufacturer's instructions (Parr Instrument Company 2008).

Carbon and nitrogen contents were measured by combusting the material and using gas chromatography to separate the resulting $\mathrm{N}_{2}$ and $\mathrm{CO}_{2}$ gases. The gases were then analysed with an Isoprime isotope ratio mass spectrometer to give total carbon and nitrogen content. An average of the carbon content ( $\mathrm{n}=68,31.35 \%$ DW) per salp for both locations was used to calculate carbon standing stock ( $\mathrm{mg} \mathrm{C} \mathrm{m} \mathrm{m}^{-2}$ ) from the carcasses observed. All salps viewed in the video transects were assumed to have a DW of $0.38 \mathrm{~g}$ (the mean of $\mathrm{n}=27$ weighed individuals), allowing carbon standing stock to be calculated per square metre. While this is an approximation, we are confident that all carcasses seen in the video and captured in benthic gear were of similar size.

\section{RESULTS}

\section{Observations of Thetys vagina on the sea floor}

Carcasses of Thetys vagina were observed in all 3 video transects in Bass Canyon and in 38 out of 46 transects on the Challenger Plateau (Fig. 2A). In total, 368 carcasses were recorded in Bass Canyon comprising $47.8 \%$ of the total observed fauna over an area of $2118 \mathrm{~m}^{2}$. The mean $( \pm \mathrm{SD})$ density of $T$. vagina was $219 \pm 168$ ind. $1000 \mathrm{~m}^{-2}$, with a minimum density of 85 and a maximum of 408 ind. $1000 \mathrm{~m}^{-2}$ (Fig. 1B). On the Challenger Plateau, 1400 individuals were observed, making up $9.8 \%$ of total observed fauna over an area of $72995 \mathrm{~m}^{2}$. In 11 transects where abundances of $T$. vagina were high (>20 ind. $1000 \mathrm{~m}^{-2}$, Fig. 1B), T. vagina carcasses ranged from 19.6 to $48.7 \%$ of the total fauna observed, similar to that found in Bass Canyon. The mean ( \pm SD) density of $T$. vagina on the Challenger Plateau was $26 \pm 39$ ind. $1000 \mathrm{~m}^{-2}$, significantly lower than densities found in Bass Canyon ( $\mathrm{p}<0.001, F_{1,48}=40.1$, ANOVA), with a minimum density of 0 and a maximum of 202 ind. $1000 \mathrm{~m}^{-2}$ (Fig. 1C). T. vagina comprised $19.0 \%$ of total haul biomass on the Challenger Plateau and $42.6 \%$ of total haul biomass in Bass Canyon and was the dominant organism in both locations (see Appendix 1). During one transect on the Challenger Plateau, the deep-water spider crab Platymaia maoria was twice observed directly feeding on T. vagina carcasses (Fig. 2B; Table 1). On 17 occasions across 9 


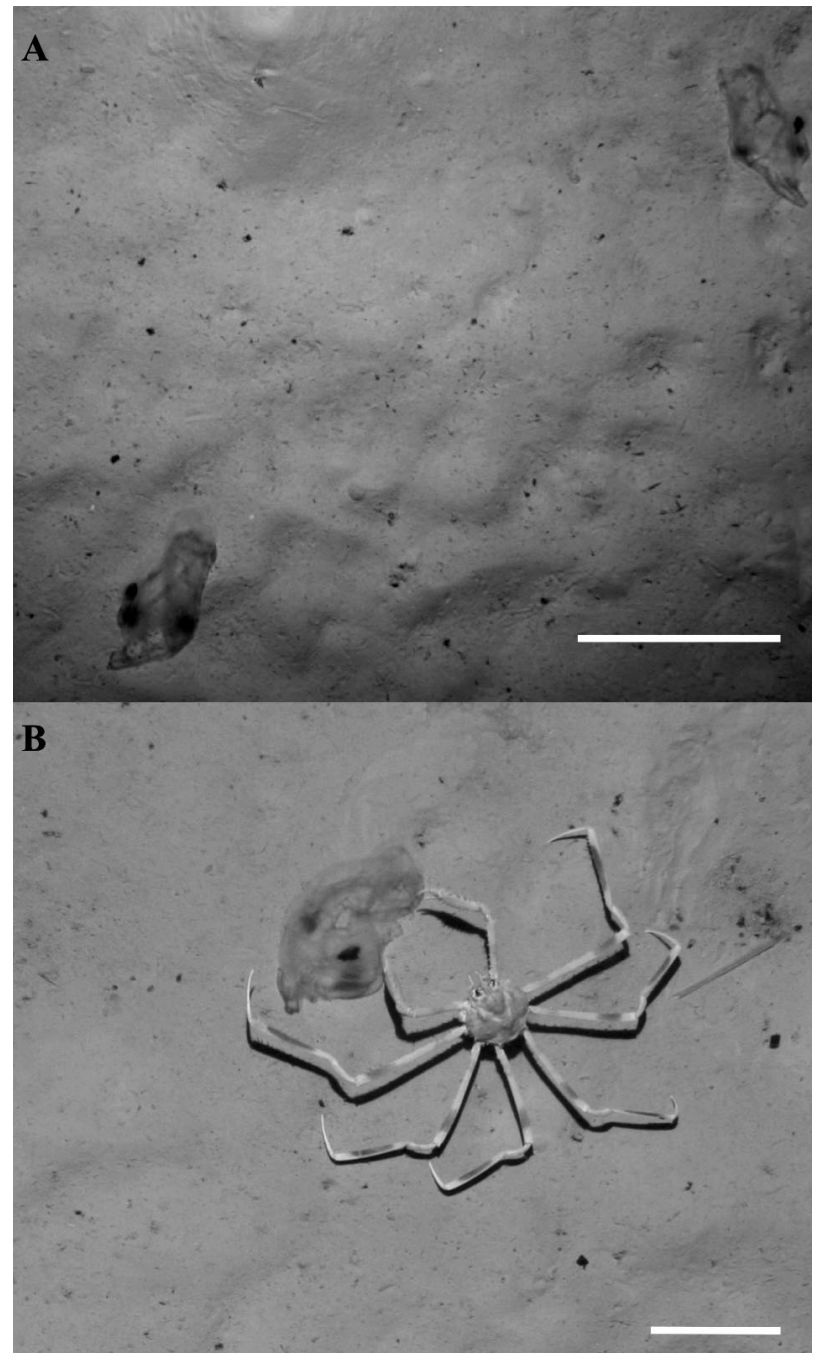

Fig. 2. Sea floor photographs from the Tasman Sea. Scale bars $=10 \mathrm{~cm}$. (A) Thetys vagina carcasses at $1565 \mathrm{~m}$ depth taken in Bass Canyon. (B) Platymaia maora feeding on

$T$. vagina carcass at $482 \mathrm{~m}$ on the Challenger Plateau

transects, demersal fish and sea stars were recorded near the carcasses (Table 1). The most common demersal fish were rattails Coelorinchus spp. and were found close to the carcasses on 10 occasions. At both locations, all $T$. vagina individuals observed on the sea floor were dead, whole and with no visible bacterial mats or biofilms.

\section{Abundance of Thetys vagina and other large salps and pyrosomes in the Tasman Sea}

Analysis of the New Zealand fisheries database from 1981 to 2011 determined that salp and pyrosome biomass exceeded $100 \mathrm{t} \mathrm{km}^{-3} \mathrm{WW}\left(56 \mathrm{t} \mathrm{km}^{-2}\right)$ in approx-
Table 1. Megafaunal taxa observed directly feeding on or close to (potential feeders) Thetys vagina carcasses on the Challenger Plateau. Footnotes b to e denote previous records of taxa feeding on salps

\begin{tabular}{|c|c|}
\hline & No. of events \\
\hline \multicolumn{2}{|l|}{ Crustacea } \\
\hline Platymaia maoria & $2^{\mathrm{a}}$ \\
\hline \multicolumn{2}{|l|}{ Fish } \\
\hline Coelorinchus sp. ${ }^{\mathrm{b}}$ & 10 \\
\hline Paraulopus sp. & 1 \\
\hline Tripterophycis gilchristi & 1 \\
\hline Helicolenus sp. ${ }^{\mathrm{c}}$ & 1 \\
\hline Hoplichthys haswelli & 1 \\
\hline Hydrolagus novaezelandiae ${ }^{\mathrm{d}}$ & 1 \\
\hline \multicolumn{2}{|l|}{ Echinodermata } \\
\hline Ophiuroidea & 2 \\
\hline Asteroidea & 1 \\
\hline $\begin{array}{l}{ }^{\mathrm{a}} \text { Direct feeding observed }{ }_{i}{ }^{\mathrm{b}} \mathrm{Cl} \\
(2000)_{i}{ }^{\mathrm{d}} \text { Dunn et al. }(2010)_{i}{ }^{\mathrm{e}} \mathrm{C}\end{array}$ & $\begin{array}{l}\text { Bax \& Williams } \\
\text { 1984) }\end{array}$ \\
\hline
\end{tabular}

imately half of the years sampled (Fig. 3A). Biomass ranged from $0.006 \mathrm{t} \mathrm{km}^{-3} \mathrm{WW}\left(0.003 \mathrm{t} \mathrm{km}^{-2}\right)$ to $1464 \mathrm{t}$ $\mathrm{km}^{-3} \mathrm{WW}\left(824 \mathrm{t} \mathrm{km}^{-2}\right)$, with a $30 \mathrm{yr}$ average $( \pm \mathrm{SD})$ of $8.54 \pm 51.79 \mathrm{t} \mathrm{km}^{-3} \mathrm{WW}\left(4.81 \mathrm{t} \mathrm{km}^{-2}\right)$. Salps and pyrosomes were present year-round but appear to form dense swarms an order of magnitude greater than their normal occurrence between December and June (Fig. 3B).

High densities of Thetys vagina were captured in 3 trans-Tasman cruises in 2008, 2009 and 2011 (Fig. $3 \mathrm{~A})$, with a maximum of $734 \mathrm{t} \mathrm{km}^{-3} \mathrm{WW}\left(147 \mathrm{t} \mathrm{km}^{-2}\right)$ caught in 2009 (minimum $=0.003 \mathrm{t} \mathrm{km}^{-3} \mathrm{WW}$, mean $\left.( \pm \mathrm{SD})=44.82 \pm 158.20 \mathrm{t} \mathrm{km}^{-3} \mathrm{WW}\right)$. Depth-stratified sampling showed that $98 \%$ of $T$. vagina biomass occurred in the top $200 \mathrm{~m}$ of the water column.

\section{Biochemical composition of Thetys vagina}

Lipids accounted for the highest proportion of macronutrients, making up a mean $( \pm \mathrm{SD})$ of $10.5 \pm$ $2.8 \%$ DW (Table 2). Protein constituted $3.4 \pm 1.5 \%$ DW, and carbohydrates constituted $4.4 \pm 1.9 \%$. The mean $( \pm \mathrm{SD})$ energetic content of Thetys vagina was $11.0 \pm 1.4 \mathrm{~kJ} \mathrm{~g}^{-1} \mathrm{DW}$. AFDW was high, ranging from 33 to $88 \%$ DW, and total organic content of $T$. vagina represented only $31 \%$ of AFDW.

Mean $( \pm \mathrm{SD})$ carbon content for Thetys vagina $(31.4 \pm 5.4 \%$ DW) was much higher than nitrogen content (2.8 $\pm 1.1 \%$ DW; Table 2$)$. Carbon standing stock of the $T$. vagina deposition in Bass Canyon was $26.1 \mathrm{mg} \mathrm{C} \mathrm{m}^{-2}$. On the Challenger Plateau, carbon standing stock was lower, with a mean of $3.1 \mathrm{mg} \mathrm{C} \mathrm{m}^{-2}$ 
Table 2. Thetys vagina. Biochemical and elemental composition. $\mathrm{n}=$ number of individuals measured

\begin{tabular}{|c|c|c|c|}
\hline & $\mathrm{n}$ & Mean $\pm \mathrm{SD}$ & Range \\
\hline Protein content (\% DW) & 68 & $3.42 \pm 1.46$ & $1.10-7.34$ \\
\hline Lipid content (\% DW) & 31 & $10.50 \pm 2.77$ & $6.19-16.48$ \\
\hline Carbohydrate content (\% DW) & 18 & $4.36 \pm 1.92$ & $1.34-7.77$ \\
\hline Energetic content $\left(\mathrm{kJ} \mathrm{g}^{-1} \mathrm{DW}\right)$ & 9 & $11.00 \pm 1.38$ & $8.91-13.33$ \\
\hline Carbon content (\% DW) & 68 & $31.35 \pm 5.34$ & $18.77-42.68$ \\
\hline Nitrogen content (\% DW) & 68 & $2.82 \pm 1.13$ & $1.52-8.09$ \\
\hline $\mathrm{C}: \mathrm{N}$ & 68 & $12.03 \pm 3.03$ & $4.73-19.05$ \\
\hline
\end{tabular}

These mean densities of $T$. vagina (26 and 219 ind. $1000 \mathrm{~m}^{-2}$ for the Challenger Plateau and Bass Canyon, respectively) are much greater than those found for depositions of the giant jellyfish Nemopilema nomurai in the sea of Japan (1.1 ind. $\left.1000 \mathrm{~m}^{-2}\right)$ (Yamamoto et al. 2008) and the deep-sea scyphozoan Periphylla periphylla in a Norwegian fjord (10 ind. $1000 \mathrm{~m}^{-2}$ ) (Sweetman \& Chapman 2011). Densities were similar to those of Pyrosoma atlanticum carcasses off but reaching $24.1 \mathrm{mg} \mathrm{C} \mathrm{m}^{-2}$ at some stations. Using $\mathrm{C}: \mathrm{N}$ ratio and energetic content as an indicator of nutritional quality, $T$. vagina is nutritionally similar to phytoplankton (Fig. 4). Values for T. vagina are much greater than reported values for cnidarians and ctenophores.

\section{DISCUSSION}

\section{Observations of Thetys vagina on the sea floor}

Densities of Thetys vagina carcasses observed on the sea floor in this study are among the highest recorded for any gelatinous zooplankton deposition. the Ivory Coast $\left(70.6\right.$ ind. $1000 \mathrm{~m}^{-2}$ ) described by Lebrato \& Jones (2009). The mass depositions of fresh carcasses observed in this study indicate the recent demise of swarms at both locations. On the Challenger Plateau, high densities of $T$. vagina were observed at the surface during sampling, suggesting that the swarm may still have been developing for several weeks after sampling. Sampling during an ongoing swarm may limit the accuracy of the deposition densities, as some salp and pyrosome species are known to migrate to sea floor depths (Roe et al. 1990, Gili et al. 2006). As T. vagina mainly occurs in the top $200 \mathrm{~m}$ of the water column and all carcasses viewed on the video were dead or moribund, it is unlikely that deposition abundances were overstated.
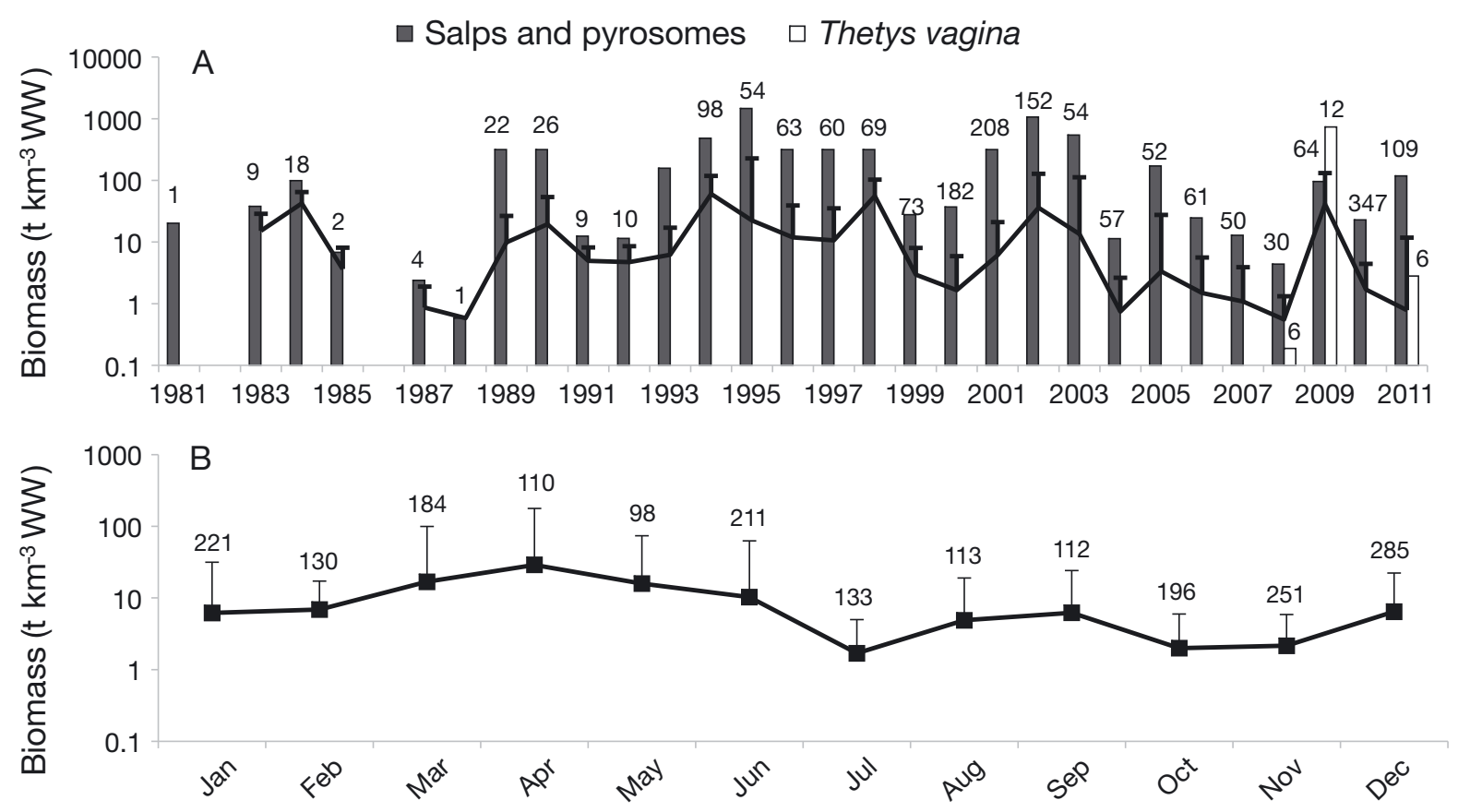

Fig. 3. (A) Maximum yearly biomass for salps and pyrosomes (dark grey bars; New Zealand fisheries database) from 1981 to 2011 and Thetys vagina (white bars; trans-Tasman pelagic trawls) in 2008, 2009 and 2011. Yearly mean (+SD) is represented by the solid line. Number of trawls per year is indicated above each bar. Station locations are presented in Fig. 1. (B) Mean (+SD) monthly biomass of salps and pyrosomes from 1981 to 2011. Number of trawls per month is indicated above each bar. $\mathrm{WW}=$ wet weight 


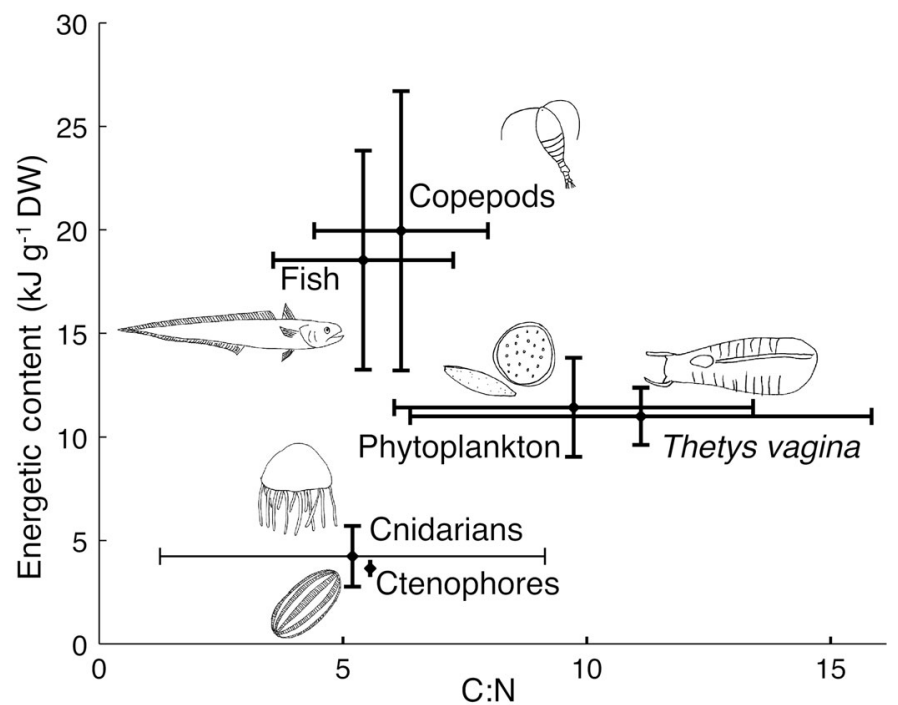

Fig. 4. Relationship between mean $( \pm \mathrm{SD})$ energetic content and mean $( \pm \mathrm{SD}) \mathrm{C}: \mathrm{N}$ ratio as an indicator of quality of different marine organisms as a food item. Values for Thetys vagina obtained from this study. Other values obtained from previous studies: phytoplankton (Platt \& Irwin 1973), copepods (Donnelly et al. 1994, Ikeda et al. 2006), cnidarians and ctenophores (Clarke et al. 1992) and fish (Childress \& Nygaard 1973). DW = dry weight

\section{Abundance of Thetys vagina and other large salps in the Tasman Sea}

Other large salps such as Salpa thompsoni (Nishikawa et al. 1995, Perissinotto \& Pakhomov 1998) and S. aspera (Wiebe et al. 1979, Madin et al. 2006) frequently form large swarms, but records of Thetys vagina are sparse. The largest swarm recorded of $T$. vagina occurred in 2004 in the Sea of Japan, with biomasses as high as $900 \mathrm{t} \mathrm{km}^{-3}$ WW (Iguchi \& Kidokoro 2006), comparable to the maximum of $734 \mathrm{t}$ $\mathrm{km}^{-3} \mathrm{WW}$ recorded in this study. As New Zealand fisheries surveys were designed for the capture of large pelagic and demersal fish, they are likely to under-represent the true abundances of salps. Trawls would only spend approximately $35 \%$ of their time in the 0 to $200 \mathrm{~m}$ depth range that is preferred by the majority of large salps in the Tasman Sea (Thompson 1948). Regardless, abundances of salps across the 30 yr dataset indicate that salp biomass in the Tasman Sea often exceeded $100 \mathrm{t} \mathrm{km}^{-3}$ WW, which is considerably higher than previously thought.

Tranter (1962) recorded an average zooplankton biomass (excluding salps) of $36 \mathrm{t} \mathrm{km}^{-3}$ WW from 1959 to 1961 in the Tasman Sea, with salps accounting for an additional $53 \mathrm{t} \mathrm{km}^{-3} \mathrm{WW}$. Maximum swarm values from the present study show that large salp and pyrosome swarms in the Tasman Sea can frequently exceed zooplankton biomass by 300\%. Similarly, Young et al. (1996) sampled zooplankton in the Tasman Sea from 1992 to 1994 and found salps on average made up $30 \%$ of zooplankton biomass across the 3 yr and at some times up to $90 \%$. To put salp biomass into perspective, hoki Macruronus novaezealandiae constitutes New Zealand's largest fishery (O'Driscoll 2004), with biomass estimated to be $1.2 \mathrm{t} \mathrm{km}^{-2} \mathrm{WW}$ (based on an 8 yr average) and representing $97 \%$ of all fish biomass in the midwater depth range (Bull et al. 2001). The mean $30 \mathrm{yr}$ average of large salp biomass (4.81 $\mathrm{t} \mathrm{km}^{-2} \mathrm{WW}$ ) for the Tasman Sea and New Zealand region not only exceeds this value but also indicates the prevalence of salp swarms in the Tasman Sea.

\section{Biochemical composition of large salps}

This study provides the first data on the biochemical composition of Thetys vagina. Results obtained are within expected ranges observed for other large salps (Madin et al. 1981, Clarke et al. 1992, Dubischar et al. 2006). Similar to our salps, higher proportions of lipids to protein are found in the Antarctic species Salpa thompsoni (5.7 to 6.8\% DW) (Dubischar et al. 2006), while the opposite trend is observed for North Atlantic salp species: 0.96, 0.25 and 0.97\% DW for Pegea confoderata, S. cylindrica and S. maxima, respectively (Madin et al. 1981). Differences in the biochemical composition of salp species are likely to arise from either differing lipid concentrations within food sources (Larson \& Harbison 1989) or environmental conditions inciting higher storage of lipids in cooler waters (Dubischar et al. 2006). Previous studies show that carbohydrate contents for salps are generally low (0.8 to $1.3 \%$ DW) (Madin et al. 1981, Clarke et al. 1992, Dubischar et al. 2006); however, this study recorded levels similar to those of protein. These higher values are consistent with expected results, as the salp tunic is mainly comprised of proteins and polysaccharides (Godeaux 1965).

Although the total organic content (lipids, proteins and carbohydrates) of an organism should equal its AFDW (Madin et al. 1981), high values of AFDW are characteristic for gelatinous zooplankton because of difficulties in removing 'water of hydration' (Madin et al. 1981) when freeze-drying. Similar AFDW values have been found for other salps: 27 to $62.7 \%$ DW for Salpa thompsoni (Huntley et al. 1989, Donnelly et al. 1994) and 66.4\% DW for $S$. fusiformis (Clarke et al. 1992), with total organic contents ranging from 19 to $51 \%$ of AFDW (Madin et al. 1981, Dubischar et al. 
2006). Apart from residual water, the most likely causes for the 'missing' compounds are those missed by the methodology. For example, as the nitrogen content of protein can be assumed to be $16 \%$ (protein $=\mathrm{N} \times 6.25$ ) (Madin et al. 1981), from the nitrogen values recorded here, protein content should have been as high as $17.6 \%$ DW, 4 times higher than our detected values. Similar problems detecting proteins in gelatinous zooplankton have been seen in previous studies (Clarke et al. 1992, Dubischar et al. 2006) and are thought to arise from problems with detecting cross-linked proteins.

\section{Contribution to the benthic food web}

Energetic content of Thetys vagina was higher than that of cnidarians and ctenophores (4.35 to $10.17 \mathrm{~kJ}$ $\mathrm{g}^{-1} \mathrm{DW}$ ) (Percy \& Fife 1981) and other pelagic tunicates such as Pyrosoma atlanticum $\left(4.94 \pm 1.55 \mathrm{~kJ} \mathrm{~g}^{-1}\right.$ DW) (Davenport \& Balazs 1991) and almost as high as some crustacean species $\left(14.77 \pm 1.67 \mathrm{~kJ} \mathrm{~g}^{-1} \mathrm{DW}\right)$ (Wacasey \& Atkinson 1987). Of all gelatinous zooplankton studied to date, carbon content for $T$. vagina was second only to $P$. atlanticum (Davenport \& Balazs 1991, Lebrato \& Jones 2009). The energetic content and $\mathrm{C}: \mathrm{N}$ ratios suggest that $T$. vagina carcasses have higher food value than other gelatinous zooplankton (cnidarians and ctenophores) (Fig. 4) and nutritionally are more similar to the phytoplankton blooms that normally sustain benthic communities (Rowe \& Staresinic 1979, Smith et al. 2008) as well as fish and copepods. As only the tunic of $T$. vagina was analysed, nutritional quality has not been elevated by gut contents. Compared to smaller salps, the tunic of $T$. vagina is relatively thick and composed of densely packed fibrous material (Hirose et al. 1999), possibly resulting in elevated nutritional values. Based on maximum salp biomass values of $100 \mathrm{t} \mathrm{km}^{-3} \mathrm{WW}$, these deposition events can potentially export up to $616 \mathrm{GJ} \mathrm{km}^{-2}$ of energy, or $16 \mathrm{t} \mathrm{km}^{-2}$ of carbon, to the Tasman Sea benthos every year.

Several fish species feed exclusively on salps or have salps as a major component of their diets. These species tend to be opportunistic bentho-pelagic feeders, such as the black oreo Allocyttus niger, smooth oreo Pseudocyttus maculatus, spiky oreo Neocyttus rhomboidalis, carinate rattail Macrourus carinatus and small-scaled brown slickhead Alepocephalus australis (Clark et al. 1989, Lyle \& Smith 1997). Our results suggest that the salp carasses often found in these fish guts may result from scavenging at the seafloor. Apart from fish, other benthic feeders including sea stars (Domanski 1984), sea urchins (Duggins 1981), octocorallians (Gili et al. 2006), mushroom corals (Hoeksema \& Waheed 2012) and, from this study, the deep-water spider crab Platymaia maora have been observed feeding on salps. Similarly, pyrosome carcasses have provided food for a range of megafauna including crustaceans, arthropods, anemones and echinoderms (Roe et al. 1990, Lebrato \& Jones 2009), while anemones, shrimp, crabs and molluscs have been observed near and feeding on cnidarian carcasses (Yamamoto et al. 2008, Sweetman \& Chapman 2011). As salp carcasses can sink at rates up to $1700 \mathrm{~m} \mathrm{~d}^{-1}$ (Lebrato et al. 2013), they will be able to reach the seafloor in less than 2 to $3 \mathrm{~d}$, before significant bacterial degradation can take place. Preliminary experimental data suggest that at seafloor temperatures $\left(4^{\circ} \mathrm{C}\right)$, Thetys vagina individuals will retain $68 \%$ of their mass after $28 \mathrm{~d}(\mathrm{~N}$. Henschke unpubl. data). These results are slower than a model-calculated decomposition time of approximately $20 \mathrm{~d}$ for a gelatinous organism, which includes more labile cnidarians (Lebrato et al. 2011). As no bacterial mats or biofilms were observed on any of the $T$. vagina individuals viewed or collected in this study, slow decomposition rates of $T$. vagina would allow carcasses to remain on the sea floor until scavenged or eventually remineralised via the microbial loop.

\section{Potential carbon standing stock}

Studies in the world's oceans (Smith \& Kaufmann 1999), including the Pacific Ocean near New Zealand (Nodder et al. 2003), have identified that food demand in the benthic community (sediment community oxygen consumption) often exceeds food supply (POM). Salp carcasses are not detected by traditional methods of sampling water column nutrient fluxes, such as sediment traps (Lebrato \& Jones 2009), and consequently are not included in current carbon budget calculations, resulting in a considerable underestimation of the total flux. Hence, salp carcasses may be supplementing the smaller POM that can be collected by sediment traps, providing an extra source of nutrition for the benthic community. Since particles that generally make up the majority of measured carbon flux in the Tasman Sea are $<1 \mathrm{~mm}$ (Kawahata \& Ohta 2000), these salp deposition events provide a substantial contribution of much larger carbon parcels to the benthos. As swarms of Thetys vagina were still in surface waters during sampling on the Challenger Plateau, by the time the 
entire population had collapsed, the input from both faecal pellets and carcasses would have been considerably higher than values estimated here.

Depositions of Thetys vagina on the Challenger Plateau in this study only represented $0.19 \%$ of the regional annual carbon flux, whereas carbon provided from the Bass Canyon deposition was 10-fold greater, representing $1.5 \%$ of the annual flux (Kawahata \& Ohta 2000). Although gelatinous zooplankton depositions can occur across all bottom topographies, studies have identified much greater biomasses and carbon inputs when organisms are in environments that promote concentration, such as canyons or structures like pipelines (Cacchione et al. 1978, Lebrato \& Jones 2009). Carbon standing stocks for cnidarian carcasses in the Arabian Sea have been reported as high as $78 \mathrm{~g} \mathrm{C} \mathrm{m}^{-2}$ in some areas, an order of magnitude higher than mean annual flux (Billett et al. 2006), and $22 \mathrm{~g} \mathrm{C} \mathrm{m}^{-2}$ has been reported for Pyrosoma atlanticum carcasses off the Ivory Coast, 13 times greater than the annual flux (Lebrato \& Jones 2009). Future studies may benefit from incorporating bottom topographies when calculating the potential for gelatinous organisms to accumulate on the sea floor and their eventual contribution to carbon fluxes in the area.

\section{Concluding remarks}

Mass depositions of salp carcasses represent a significant pathway for the export of organic production from surface waters to the deep sea. Salp biomass in the Tasman Sea regularly exceeds $100 \mathrm{t} \mathrm{km}^{-3} \mathrm{WW}$, with deposition events likely to export at least $16 \mathrm{t}$ $\mathrm{km}^{-2}$ of carbon, or $616 \mathrm{GJ} \mathrm{km} \mathrm{km}^{-2}$ of energy, to the benthos every year. With higher organic content than depositions of other gelatinous organisms, the input of large salp carcasses (salp-fall) is likely to be important to the nutritional ecology of the deep-sea benthos.

Acknowledgements. This research could not have been completed without the kind and gracious assistance of S. Mills and Dr. K. Schnabel from the Marine Invertebrate Collection at NIWA; M. Lewis from CSIRO; and Dr. M. Cryer and C. Loveridge from the Ministry of Fisheries, New Zealand. We also thank M. Gall (UWS) for her assistance with the biochemical analysis of the specimens and A. Hart (NIWA) for fish identification. We are grateful to the anonymous reviewers for their helpful comments that improved on the original version of this manuscript. The New Zealand samples were collected under the Ocean Survey 20/20 Chatham/Challenger Biodiversity and Seabed Habitat project, funded jointly by the New Zealand Ministry of Fish- eries, Land Information New Zealand, NIWA and the New Zealand Department of Conservation. The Australian samples were collected during a Next Wave transit voyage (SS03-2009) funded by the Marine National Facility. This is contribution 110 from the Sydney Institute of Marine Science.

\section{LITERATURE CITED}

Alldredge AL, Silver MW (1988) Characteristics, dynamics and significance of marine snow. Prog Oceanogr 20: $41-82$

Bax N, Williams A (2000) Habitat and fisheries production in the south east fishery ecosystem. Final Report to the Fisheries Research and Development Corporation, Project No. 94/040, CSIRO Marine Research, Hobart

Berrill NJ (1950) Order Salpida (Demomyaria). In: The Tunicata, with an account of the British species, Vol 133. Ray Society, London, p 286-301

Billett DSM, Bett BJ, Jacobs CL, Rouse IP, Wigham BD (2006) Mass deposition of jellyfish in the deep Arabian Sea. Limnol Oceanogr 51:2077-2083

Bowden DA, Schiaparelli S, Clark MR, Rickard GJ (2011) A lost world? Archaic crinoid-dominated assemblages on an Antarctic seamount. Deep-Sea Res II 58:119-127

Bradford MM (1976) A rapid and sensitive method for the quantitation of microgram quantities of protein utilizing the principle of protein-dye binding. Anal Biochem 72: 248-254

Bull B, Livingston ME, Hurst R, Bagley N (2001) Upper-slope fish communities on the Chatham Rise, New Zealand, 1992-99. NZ J Mar Freshw Res 35:795-815

> Butman CA, Carlton JT, Palumbi SR (1995) Whaling effects on deep-sea biodiversity. Conserv Biol 9:462-464

Cacchione DA, Rowe GT, Malahoff A (1978) Submersible investigation of outer Hudson submarine canyon. In: Stanley DJ, Kelling G (eds) Sedimentation in submarine canyons, fans and trenches. Dowden Hutchinson \& Ross, Stroudsburg, PA, p 42-50

Childress JJ, Nygaard MH (1973) The chemical composition of midwater fishes as a function of depth of occurrence off southern California. Deep-Sea Res 20:1093-1109

Clark MR (1985) The food and feeding of seven fish species from the Campbell Plateau, New Zealand. NZ J Mar Freshw Res 19:339-363

- Clark MR, King KJ, McMillan PJ (1989) The food and feeding relationships of black oreo, Allocyttus niger, smooth oreo, Pseudocyttus maculatus, and eight other fish species from the continental slope of the south-west Chatham Rise, New Zealand. J Fish Biol 35:465-484

> Clarke A, Holmes LJ, Gore DJ (1992) Proximate and elemental composition of gelatinous zooplankton from the Southern Ocean. J Exp Mar Biol Ecol 155:55-68

Davenport J, Balazs GH (1991) Fiery bodies-are pyrosomas an important component of the diet of leatherback turtles? Brit Herpetol Soc Bull 37:33-38

Domanski PA (1984) Giant larvae: prolonged planktonic larval phase in the asteroid Luidia sarsi. Mar Biol 80: 189-195

> Donnelly J, Torres JJ, Hopkins TL, Lancraft TM (1994) Chemical composition of Antarctic zooplankton during austral fall and winter. Polar Biol 14:171-183

> Dubischar CD, Pakhomov E, Bathmann UV (2006) The tunicate Salpa thompsoni ecology in the Southern Ocean II. 
Proximate and elemental composition. Mar Biol 149: 625-632

- Dubois M, Gilles KA, Hamilton JK, Rebers PA, Smith F (1956) Colorimetric method for determination of sugars and related substances. Anal Chem 28:350-356

Duggins DO (1981) Sea urchins and kelp: the effects of short term changes in urchin diet. Limnol Oceanogr 26: 391-394

> Dunn MR, Griggs L, Forman J, Horn P (2010) Feeding habits and niche separation among the deep-sea chimaeroid fishes Harriotta raleighana, Hydrolagus bemisi and Hydrolagus novaezealandiae. Mar Ecol Prog Ser 407:209-225

$>$ Folch J, Lees M, Sloane Stanley GH (1957) A simple method for the isolation and purification of total lipides from animal tissues. J Biol Chem 226:497-509

Gili JM, Rossi S, Pages F, Orejas C, Teixido N, LopezGonzalez PJ, Arntz WE (2006) A new trophic link between the pelagic and benthic systems on the Antarctic shelf. Mar Ecol Prog Ser 322:43-49

Godeaux J (1965) Observations sur la tunique des tuniciers pelagiques. Rapp Comm Int Mer Médit 18:457-460

> Gooday AJ (2002) Biological responses to seasonally varying fluxes of organic matter to the ocean floor: a review. J Oceanogr 58:305-332

> Grassle JF, Morse-Porteous LS (1987) Macrofaunal colonization of disturbed deep-sea environments and the structure of deep-sea benthic communities. Deep-Sea Res Part A 34:1911-1950

Hill P (2009) Designing a deep-towed camera vehicle using single conductor cable. Sea Technol 50:49-51

> Hirose E, Kimura S, Itoh T, Nishikawa J (1999) Tunic morphology and cellulosic components of pyrosomas, doliolids, and salps (Thaliacea, Urochordata). Biol Bull 196: 113-120

> Hoeksema BW, Waheed Z (2012) It pays to have a big mouth: mushroom corals ingesting salps at northwest Borneo. Mar Biodiversity 42:297-302

> Huntley ME, Sykes PF, Marin V (1989) Biometry and trophodynamics of Salpa thompsoni Foxton (Tunicata, Thaliacea) near the Antarctic Peninsula in austral summer, 1983-1984. Polar Biol 10:59-70

Iguchi N, Kidokoro H (2006) Horizontal distribution of Thetys vagina Tilesius (Tunicata, Thaliacea) in the Japan Sea during spring 2004. J Plankton Res 28:537-541

> Ikeda T, Yamaguchi A, Matsuishi T (2006) Chemical composition and energy content of deep-sea calanoid copepods in the western North Pacific Ocean. Deep-Sea Res I 53:1791-1809

Kawahata H, Ohta H (2000) Sinking and suspended particles in the south-west Pacific. Mar Freshw Res 51: 113-126

Larson RJ, Harbison GR (1989) Source and fate of lipids in polar gelatinous zooplankton. Arctic 42:339-346

Lebrato M, Jones DOB (2009) Mass deposition event of Pyrosoma atlanticum carcasses off Ivory Coast (West Africa). Limnol Oceanogr 54:1197-1209

Lebrato M, Pahlow M, Oschlies A, Pitt KA, Jones DOB, Molinero JC, Condon RH (2011) Depth attenuation of organic matter export associated with jelly falls. Limnol Oceanogr 56:1917-1928

> Lebrato M, Pitt K, Sweetman A, Jones D and others (2012) Jelly-falls historic and recent observations: a review to drive future research directions. Hydrobiologia 690: $227-245$

> Lebrato M, de Jesus Mendes P, Steinberg DK, Cartes JE and others (2013) Jelly biomass sinking speed reveals a fast carbon export mechanism. Limnol Oceanogr 58:1113-1122

Lyle JM, Smith DC (1997) Abundance and biology of warty oreo (Allocyttus verrucosus) and spikey oreo (Neocyttus rhomboidalis) (Oreosomatidae) off south-eastern Australia. Mar Freshw Res 48:91-102

- Madin LP, Cetta CM, McAlister VL (1981) Elemental and biochemical composition of salps (Tunicata: Thaliacea). Mar Biol 63:217-226

> Madin LP, Kremer P, Wiebe PH, Purcell JE, Horgan EH, Nemazie DA (2006) Periodic swarms of the salp Salpa aspera in the slope water off the NE United States: biovolume, vertical migration, grazing, and vertical flux. Deep-Sea Res I 53:804-819

> Mitchell JK, Holdgate GR, Wallace MW, Gallagher SJ (2007) Marine geology of the Quaternary Bass Canyon system, southeast Australia: a cool-water carbonate system. Mar Geol 237:71-96

- Moline MA, Claustre H, Frazer TK, Schofield O, Vernet M (2004) Alteration of the food web along the Antarctic Peninsula in response to a regional warming trend. Glob Change Biol 10:1973-1980

> Moseley HN (1880) Deep-sea dredging and life in the deep sea. Nature 21:591-593

Nakamura EL, Yount JL (1958) An unusually large salp. Pac Sci 12:181

- Nishikawa J, Naganobu M, Ichii T, Ishii H, Terazaki M, Kawaguchi K (1995) Distribution of salps near the south Shetland Islands during austral summer, 1990-1991 with special reference to krill distribution. Polar Biol 15:31-39

Nodder SD, Pilditch CA, Probert PK, Hall JA (2003) Variability in benthic biomass and activity beneath the Subtropical Front, Chatham Rise, SW Pacific Ocean. Deep-Sea Res I 50:959-985

O'Driscoll RL (2004) Estimating uncertainty associated with acoustic surveys of spawning hoki (Macruronus novaezelandiae) in Cook Strait, New Zealand. ICES J Mar Sci 61:84-97

Parr Instrument Company (2008) 6200 Calorimeter Operating Instruction Manual No. 442M. Moline, IL

Percy JA, Fife FJ (1981) The biochemical composition and energy content of Arctic marine macrozooplankton. Arctic 34:307-313

Perissinotto R, Pakhomov EA (1998) Contribution of salps to carbon flux of marginal ice zone of the Lazarev Sea, Southern Ocean. Mar Biol 131:25-32

Platt T, Irwin B (1973) Caloric content of phytoplankton. Limnol Oceanogr 18:306-310

Roe HSJ, Billett DSM, Lampitt RS (1990) Benthic/midwater interactions on the Madeira Abyssal Plain; evidence for biological transport pathways. Prog Oceanogr 24: $127-140$

Rowe GT, Staresinic N (1979) Sources of organic matter to the deep-sea benthos. Ambio Spec Rep 6:19-23

Sherlock M, Kloser R, Williams A, Ryan T (2010) A combined benthic grab and observation system for rapid assessment of water column and seabed. In: Proc OCEANS'10 Institute of Electrical and Electronics Engineers Conf, Sydney, Australia, May 24-27, 2010, p 1-5

Smith CR, Baco AR (2003) Ecology of whale falls at the deep-sea floor, Vol 41. Taylor \& Francis, London

Smith KL, Kaufmann RS (1999) Long-term discrepancy between food supply and demand in the deep eastern North Pacific. Sci 284:1174-1177

Smith CR, De Leo FC, Bernardino AF, Sweetman AK, Arbizu 
PM (2008) Abyssal food limitation, ecosystem structure and climate change. Trends Ecol Evol 23:518-528

Stockton WL, DeLaca TE (1982) Food falls in the deep sea: occurrence, quality, and significance. Deep-Sea Res I 29:157-169

Sweetman AK, Chapman A (2011) First observations of jelly-falls at the seafloor in a deep-sea fjord. Deep-Sea Res I 58:1206-1211

Sweetman AK, Witte U (2008) Response of an abyssal macrofaunal community to a phytodetrital pulse. Mar Ecol Prog Ser 355:73-84

Thompson H (1948) Pelagic tunicates of Australia. Commonwealth Council for Scientific and Industrial Research, Melbourne, p 136-139

Tranter DJ (1962) Zooplankton abundance in Australasian waters. Mar Freshw Res 13:106-142

> Wacasey JW, Atkinson EG (1987) Energy values of marine benthic invertebrates from the Canadian Arctic. Mar Ecol Prog Ser 39:243-250

> Wiebe PH, Madin LP, Haury LR, Harbison GR, Philbin LM (1979) Diel vertical migration by Salpa aspera and its potential for large-scale particulate organic matter transport to the deep-sea. Mar Biol 53:249-255

Witte U, Pfannkuche O (2000) High rates of benthic carbon remineralisation in the abyssal Arabian Sea. Deep-Sea Res II 47:2785-2804

Wood RA (1991) Structure and seismic stratigraphy of the western Challenger Plateau. NZ J Geol Geophys 34:1-9

Yamamoto J, Hirose M, Ohtani T, Sugimoto K and others (2008) Transportation of organic matter to the sea floor by carrion falls of the giant jellyfish Nemopilema nomurai in the Sea of Japan. Mar Biol 153:311-317

Young JW, Bradford RW, Lamb TD, Lyne VD (1996) Biomass of zooplankton and micronekton in the southern bluefin tuna fishing grounds off eastern Tasmania, Australia. Mar Ecol Prog Ser 138:1-14

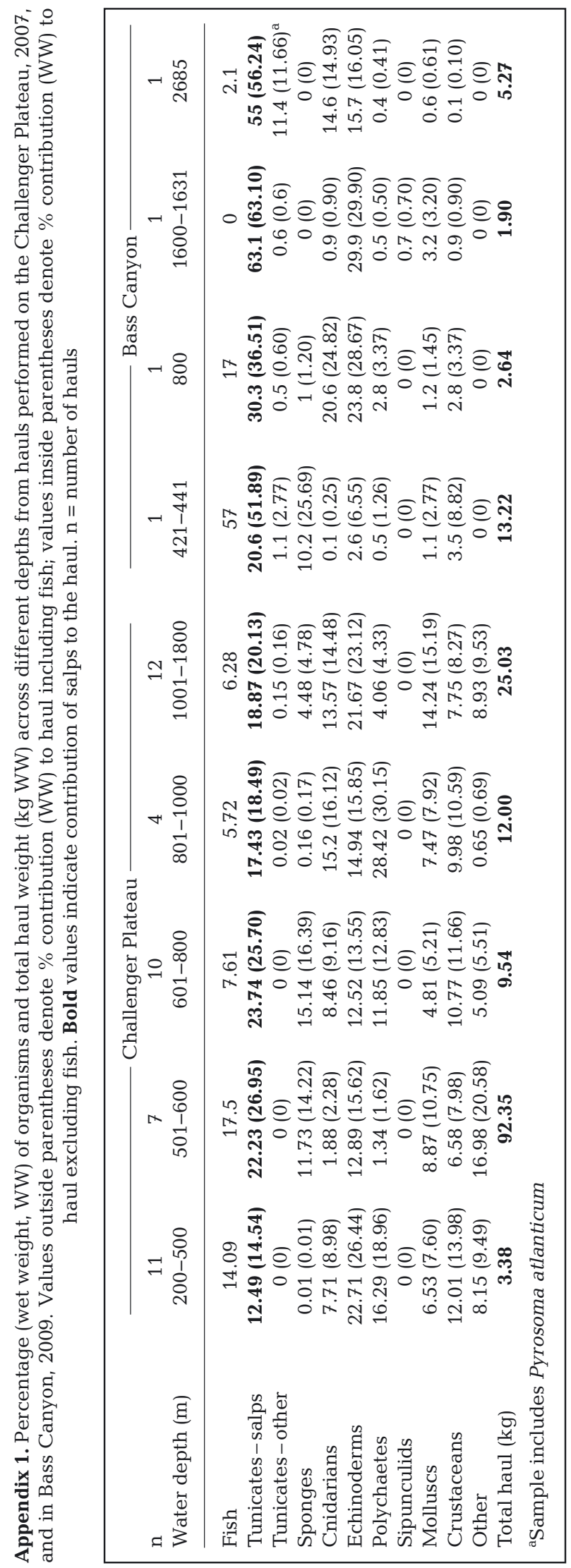

Submitted: November 13, 2012; Accepted: June 17, 2013 Proofs received from author(s): September 13, 2013 